\title{
DISPERSAL OF SEEDS UNDER ISOLATED GORSE PLANTS AND THE IMPACT OF SEED-FEEDING INSECTS
}

\author{
R.L. HILL ${ }^{1}$, A.H. GOURLAY ${ }^{1}$, W.G. LEE ${ }^{2}$ and J.B.WILSON ${ }^{3}$ \\ ${ }^{1}$ Manaaki Whenua - Landcare Research, PO Box 69 Lincoln \\ ${ }^{2}$ Manaaki Whenua - Landcare Research, Private Bag 1930, Dunedin \\ ${ }^{3}$ Botany Department, University of Otago, PO Box 56, Dunedin
}

\begin{abstract}
The rate and pattern of seed dispersal of Ulex europaeus were studied under 10 isolated 6-year-old plants in Canterbury over two years. To determine the impact of the introduced seed-feeding weevil Apion ulicis, half of the gorse plants were treated with insecticide in the second year. Seedfall and seed density were greatest at the canopy edge (39.4\% of the seed recorded fell within the canopy at a density of up to 2120 seeds $/ \mathrm{m}^{2}$ in the first year). Very few seeds were collected at 2.4 $-2.5 \mathrm{~m}$ from the centre of the bush. The seed-feeding weevil significantly reduced the number of seeds shed per bush to $45 \%$ of that shed by uninfected bushes, but this had no consistent effect on the spatial pattern of seed dispersal at the site. Results suggest that clearing $1.5 \mathrm{~m}$ tall gorse to within approximately $5 \mathrm{~m}$ of boundaries should effectively prevent explosive spread of gorse seed to adjoining areas.
\end{abstract}

Keywords: Ulex europaeus, gorse, seed dispersal, seed predation, weeds

\section{INTRODUCTION}

Gorse (Ulex europaeus L.) is a serious woody weed in agricultural and natural ecosystems in many parts of the world. Seeds provide the mechanism by which gorse invades new habitats or maintains its presence in old ones. A better understanding of how seed spreads could help develop policies for excluding gorse from pristine habitats and minimising reinvasion of areas from which gorse has already been cleared. Given the importance of dispersal in the ecology of weeds, it is surprising that studies of seed dispersal patterns of plants like gorse and broom which disperse their seeds explosively are rare (Allen et al. 1995).

Biological control is being developed as a management tool for gorse control in New Zealand and several other countries. A number of potential biological control agents have been identified and studies are underway to determine which are the most effective and appropriate. Among these is the gorse seed weevil (Apion ulicis Forst.), which was released in New Zealand in 1931. Cowley (1983) has measured 36\% infestation of pods over 12 months at one site near Auckland. Another insect, the gorse pod moth (Cydia succedana D\&S)(Lepidoptera: Tortricidae), was introduced in 1992, and has become established here. This should further reduce the annual national seed crop (Hill and Gourlay, unpublished data) but the impact of such a reduction on the spread and persistence of gorse is uncertain. This study investigates the density and pattern of seed fall beneath gorse plants as a basis for estimating the impact of seed feeders on short-distance dispersal, and conducts a small-scale assessment of the level of seed reduction associated with gorse seed weevil attack. Information on the distance seed is dispersed directly from bushes also provides useful information for establishing how far from boundaries farmers must clear gorse to minimise colonisation of neighbouring properties. 


\section{METHODS}

The study was conducted on the northwest edge of a 15-year-old plantation of Pinus radiata D. Don. at Burnham, Canterbury. Gorse was widespread along the margins and although slightly shaded, the plants were not visibly different from those growing in full sunlight. The plantation trees sheltered the site from wind in the southerly and easterly quarters. Ten spring-flowering, $1.0-1.6 \mathrm{~m}$ tall gorse plants aged 6 years old were chosen at random. All other gorse bushes within a $6 \mathrm{~m}$ radius of each bush were cleared and the remaining vegetation maintained at a low level $(<0.1 \mathrm{~m})$ throughout the experiment.

Four boards were laid on the ground around the base of the bush at right angles to each other, and oriented north, south, east and west. Each board was $2.5 \mathrm{~m}$ long and marked at $0.1 \mathrm{~m}$ intervals. The inner $1.5 \mathrm{~m}$ of board was $0.2 \mathrm{~m}$ wide, the next $0.5 \mathrm{~m}$ was $0.3 \mathrm{~m}$ wide and the remaining $0.5 \mathrm{~m}$ was $0.4 \mathrm{~m}$ across. The wider boards improved estimates where seedfall density was low. Boards were coated with a thick layer of grease (Waxrex 72 - Mobil) which, in controlled artificial seed releases from a height of $1.5 \mathrm{~m}$ and over distances of up to $2.0 \mathrm{~m}$, trapped virtually all falling seeds. The grease remained effective for up to two sampling occasions (months), and was replaced when necessary. It was assumed that no seeds were lost from the grease during each sampling period.

Seedfall beneath the bushes was monitored monthly from November 1985, and in the next 5 months, seeds were recorded on the boards only on 16 January 1986 and 11 February 1986. In January 1986, 20 pods were selected randomly from each bush and dissected. Preliminary research indicated that this sampling method provided reliable estimates of the percentage of pods infested by gorse seed weevil. The number of seeds destroyed in each pod and the number of seeds/pod were recorded. In August 1986 bushes were paired according to size, growth form and flowering phenology. One plant of each pair was randomly chosen, and sprayed to run-off with $6 \mathrm{~g} / \mathrm{l}$ of the insecticide bromophos to eliminate gorse seed weevils. The partner-bush was sprayed with a similar amount of water. The treatments were repeated fortnightly until midDecember 1986, by which time weevils had ceased to lay eggs. Pod infestation measurements were repeated in October 1986, three months after the commencement of the spraying treatments. Fall of seed was measured under both treated and untreated plants on 21 November (when only two bushes yielded seeds), 23 December 1986 and 23 January 1987.

\section{Seedfall density and pattern}

\section{RESULTS}

The average height of the gorse plants was $1.3 \mathrm{~m}$ (range $1.0-1.6 \mathrm{~m}$ ) and the average canopy radius was $0.6 \mathrm{~m}$ (range $0.45-0.7 \mathrm{~m}$ ). Fig. 1 shows the pattern of seedfall with increasing distance from the bushes for all seed falling over the first year. Most seed was deposited inside the canopy (39\% of the seed collected) or within $1 \mathrm{~m}$ of the centre of the bush $(55.7 \%)$ with a peak at the canopy margin. Seed fall continued to decline with distance away from the canopy edge until only $1.9 \%$ of the seed collected fell at the greatest distance measured $(2.4-2.5 \mathrm{~m})$. Similar patterns were recorded in year 2 , both in the presence and absence of gorse seed weevil (Fig. 2)

Over the first year, seed density was highest within the canopy area, and peaked at $2120 \mathrm{seeds} / \mathrm{m}^{2}$ at $0.3-0.4 \mathrm{~m}$ from the centre of the bush. Seed density fell below 500 seeds $/ \mathrm{m}^{2}$ at $1 \mathrm{~m}$ from the centre of the bush, and declined to $85 \mathrm{seeds} / \mathrm{m}^{2}$ at $2.5 \mathrm{~m}$. It is difficult to extrapolate beyond the data, but seedfall beyond $3 \mathrm{~m}$ must have been very low.

\section{Impact of gorse seed weevil on seedfall}

Prior to the insecticide treatments the percentage of pods infected by gorse seed weevil varied considerably between bushes, ranging from zero (three bushes) to $100 \%$. The percentage pod infestation was significantly $(\mathrm{P}<0.05)$ and linearly related to the percentage of damaged seeds present in the pods, but unrelated to the mean number of seeds per pod $(\mathrm{P}>0.05)$. For the same parameters, post-treatment results were adjusted for any pre-treatment differences that existed between the bushes. The 


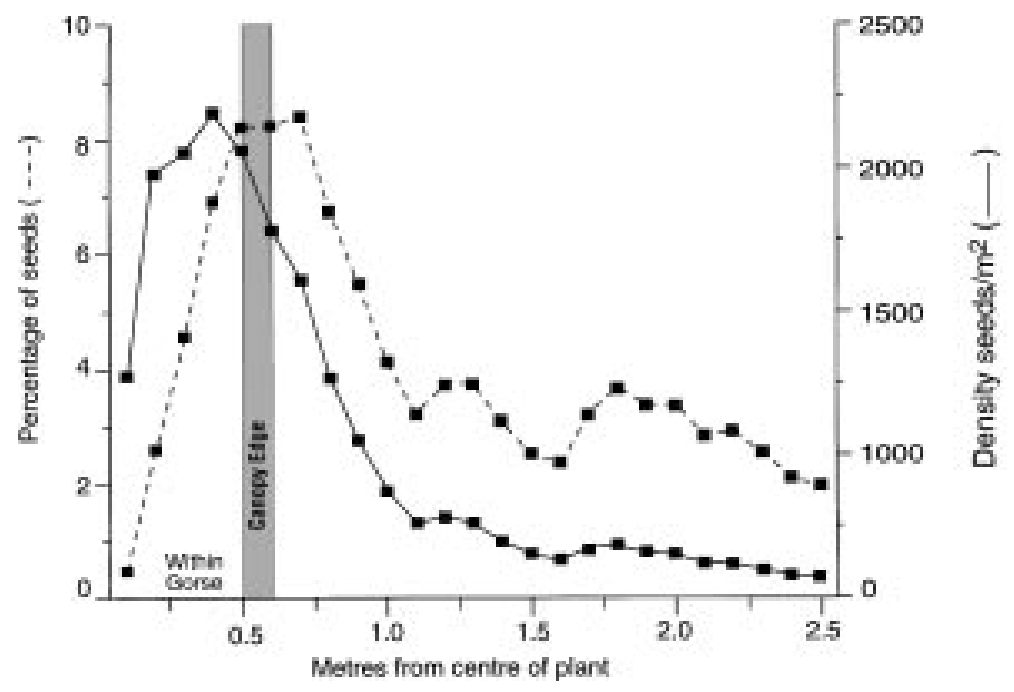

FIGURE 1: Variation in the mean density of gorse seed falling with increasing distance from an isolated parent plant, and the proportion of all seed collected falling at each distance (year 1).

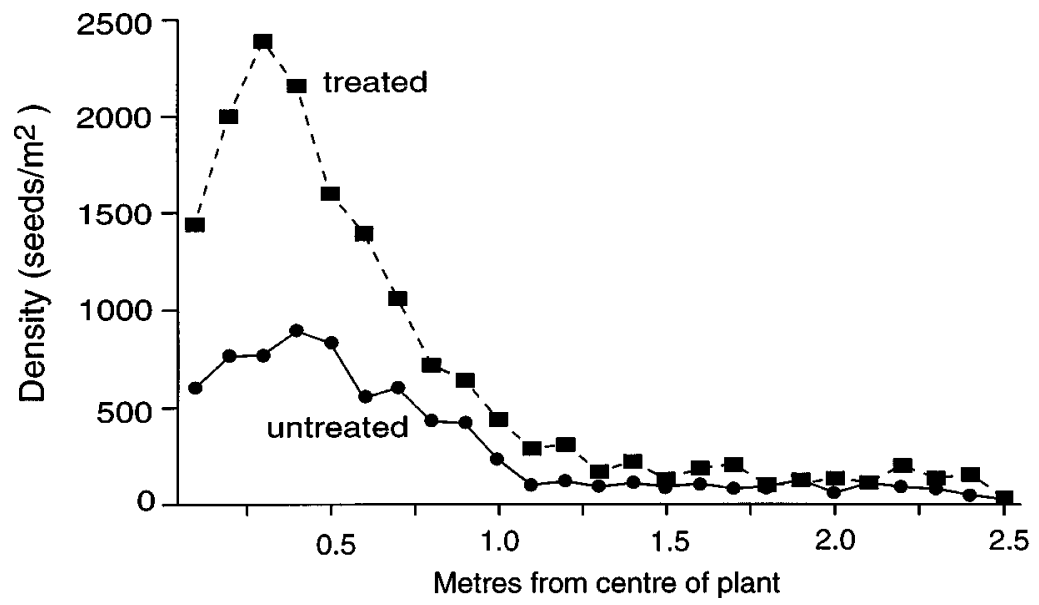

FIGURE 2: Variation in the mean density of gorse seed falling with increasing distance from parent plants with and without insecticide treatment to remove gorse seed weevil (year 2).

differences between insecticide-sprayed and water-sprayed bushes in October 1986 (after the treatments commenced) were compared using analysis of covariance, with the values for the same bushes in January 1986 (before treatments) as the covariate. All percentage data were arcsine transformed to satisfy the requirements for normal distribution, with the exception of the seeds per pod data which showed no tendency for the variance to be correlated with the mean. 
The insecticide (IS) treatment significantly reduced the presence and impact of gorse seed weevil compared with the water-sprayed bushes (WS). For IS treatments, the percentage of infected pods (adjusted means: IS $=4.3 \%$, WS $=43.4 \% ; \mathrm{P}<0.01$ ) and the percentage damaged seed (adjusted means: IS $=0.1 \%, \mathrm{WS}=32.0 \% ; \mathrm{P}<0.01$ ) were all lower, while the number of seeds/undamaged pod (IS $=4.3, \mathrm{WS}=2.6 ; \mathrm{P}<$ 0.05) was significantly higher than on water-sprayed bushes.

Seedfall was measured twice following the insecticide treatment (23 December 1986 and 23 January 1987). On both occasions, significantly less seed fell beneath water-sprayed bushes (mean of $45 \%$ of insecticide-treated plants). There was no treatment effect on either the direction or distance of seedfall (Fig. 2).

\section{DISCUSSION}

In most plant species the majority of seeds are deposited beneath the canopy of the parent plant, irrespective of the mode of dispersal. This was equally true for gorse. The density of seedfall at the extremity of the boards was low, which suggests that little seed produced by these bushes would fall further than $2.5 \mathrm{~m}$ from the centre of the bush. Given the low probability of successful recruitment of an individual gorse seed, it is not likely that this seed would cause massive colonisation by gorse in the short term, although establishment of isolated plants could eventually expand the distribution of the weed. In a seedbank study, Ogle-Mannering (1995) found that gorse seed was absent in the soil of a forest community despite the presence of 36-year-old mixed gorse/mahoe vegetation with a large gorse seedbank only 5-6 m away. This study also suggests that gorse seed disperses relatively short distances from the edge of infestations by explosive means alone. Other dispersal mechanisms, such as carriage by animals, probably play a significant role in colonisation by gorse. Seedbank accumulation patterns (Smith and Harlen 1991; Allen et al. 1995) indicate that seed shed by broom, another plant with explosive seed pods, also travels only a short distance (less than 3.5 m) from isolated parent bushes.

This experiment was conducted on flat ground. Explosive dispersal, and water or litter movement would be expected to disperse gorse seeds further downhill than on flat ground or uphill (although this was not tested here). The gorse plants averaged only $1.3 \mathrm{~m}$ in height. Taller bushes would distribute seed further but the distribution curve would have a similar shape, and it remains unlikely that large amounts of seed would disperse beyond $5 \mathrm{~m}$.

In this study seedfall densities within the plant canopy were regularly greater than 1500 seeds $/ \mathrm{m}^{2} /$ year. The average density over the $2.5 \mathrm{~m}$ radius area was 677 seeds/ $\mathrm{m}^{2}$, similar to the seedfall recorded by Ivens (1978). Ogle-Mannering (1995) estimated that gorse accumulated in the seed bank at Deborah Bay at $254-603$ seeds $/ \mathrm{m}^{2} /$ year. This rate is also consistent with the annual seedfall density recorded here.

In this study, gorse seed weevil caused a significant reduction (up to 40\%) in the amount of seed falling beneath gorse bushes. However, this may not have any impact on either the invasion rate, or persistence of gorse because of the high numbers of undamaged seed remaining and the large size of the accumulating soil seed bank. Noble and Weiss (1989) modelled the level of predispersal seed predation required to control the perennial shrub Chrysanthemoides monilifera in Australia and concluded that effective control via seed predation would only occur when more than $95 \%$ of the seeds were destroyed consistently throughout the year. This level of predispersal seed predation is unlikely to occur with a single seed predator. Our early measurements of seed predation by gorse seed weevil and gorse pod moth acting together at one site suggest that $90 \%$ reduction in annual seed crop is possible. It remains to be seen whether such a reduction leads to suppression of gorse populations, but it would reduce the amount of seed falling at a long distance from plants.

Regional Councils attempt to limit the spread of gorse by requiring landowners to clear gorse from boundaries adjoining gorse-free land. In the 14 Regional Pest Management Strategies that are being drafted at present, nine require gorse to be cleared $10 \mathrm{~m}$ from the boundary, three require $20 \mathrm{~m}$, and one requires $4 \mathrm{~m}$. The results of this study suggest that a clearance distance of $5 \mathrm{~m}$ would probably contain almost 
all of the gorse seed that falls directly from bordering plants. Seed falling beyond $5 \mathrm{~m}$ could lead to the establishment of occasional plants, which might be ecologically important in the invasion of pristine habitats, but the probability of a significant infestation developing directly from this seed is low. In conclusion, a boundary clearance requirement of $5-10 \mathrm{~m}$ (depending on the height of bordering plants) would probably be adequate to minimise the risk of mass invasion of adjoining land.

Increased predation of gorse seed by introduced natural enemies will reduce the mass dispersal of seed by any means, and further reduce the probability of colonisation distant from the parent plant.

\section{ACKNOWLEDGEMENTS}

We thank Andrew Wallace (Crop \& Food Research) for preliminary analyses of this data. The research was partially funded by the Foundation for Research, Science and Technology under contract No. C09403 (RLH and AHG) and No. C09311 (WGL). We also thank Trevor Partridge and Peter Williams for helpful comments on the manuscript.

\section{REFERENCES}

Allen, R.B., Williams, P.A. and Lee, W.G.,1995. Seed bank accumulation of broom (Cytisus scoparius) in South Island. Proc. 48th N.Z. Plant Prot.Conf.: 276-280.

Cowley, J., 1983. Life cycle of Apion ulicis (Coleoptera: Apionidae), and gorse seed weevil attack around Auckland, New Zealand. N.Z. J. Zool. 10: 83-86.

Ivens, G., 1978. Some aspects of seed ecology of gorse .Proc. 31 st N.Z. Weed and Pest Control Conf.: 53-57.

Noble, I.R. and Weiss, P.W., 1989. Movement and modelling of buried seed of the invasive perennial Chrysanthemoides monilifera in coastal dunes and biological control. Aust. J. Ecol. 9: 93-98.

Ogle-Mannering, M., 1995. Establishment of weedy species in the gorse-forest succession. $\mathrm{PhD}$ thesis, Otago University.

Smith, J.M.B. and Harlen, R.L., 1991. Preliminary observations on seed dynamics of broom (Cytisus scoparius) at Barrington Tops, New South Wales. Plant Prot. Quarterly 6: 73-78 